\section{Screening for Resistance to Pythium Root Rot among Twenty-three Caladium Cultivars}

\author{
Zhanao Deng ${ }^{1}$, Brent K. Harbaugh ${ }^{2}$, Rick O. Kelly², \\ Teresa Seijo ${ }^{2}$, and Robert J. McGovern ${ }^{3}$
}

\begin{abstract}
AdDitional INDEX words. Araceae, Caladium $\times$ bortulanum, disease resistance, resistant cultivar

Summary. Caladiums (Caladium $\times$ bortulanum) are widely grown as pot or landscape plants for their attractive leaves. Pythium root rot (Pythium myriotylum) is one of the most damaging diseases in caladium, severely reducing plant growth, aesthetic value, and tuber yield. Twenty-three commercial cultivars were inoculated with three aggressive isolates of $P$. myriotylum and evaluated for their resistance to root rot. Three cultivars, 'Apple Blossom', 'Blizzard', and 'Etta Moore', were found to have a moderate level of resistance (partial resistance) to pythium root rot. The rest of these cultivars were susceptible or highly susceptible to Pythium infection, losing up to $94 \%$ of their root tissue to rotting within 10 days after inoculation. Data indicated a linear relationship between root rot severity and leaf loss severity on Pythium-inoculated plants and highlight the importance of controlling pythium root rot in caladium pot plant and tuber production.

Comparison of some recent releases with their parents for pythium root rot resis tance suggests the potential of developing new resistant caladium cultivars using the identified sources of resistance.
\end{abstract}

$\mathrm{P}$ ythium root rot is one of the most damaging diseases of caladium. The causal agent was identified as Pythium myriotylum (Ridings and Hartman, 1976). Pythium infection causes significant losses of plant root systems and leaves, reduced plant growth and tuber production, and delayed leaf sprouting (Chase, 1987; Deng et al., 2005; Ridings and Hartman, 1976). When caladium tubers were grown in substrates infected with Pythium, sprouting was delayed 3-5 weeks, plant growth decreased up to $70 \%$, and tuber yield lost up to $40 \%$ (Ridings and Hartman, 1976). Young plants ( 3 months old) of susceptible caladium cultivars lost up to

${ }^{1,2}$ University of Florida/IFAS, Environmental Horticulture Department, Gulf Coast Research and Education Center, 14625 CR672, Wimauma, FL 33598.

${ }^{3}$ University of Florida, Doctor of Plant Medicine Degree Program, 1453 Fifield Hall, Gainesville, FL 32611.

We thank Nancy West, Joyce Jones, and Gail Bowman for their excellent technical support. This research was supported by the Florida Agricultural Experiment Station and grants from the USDA/CSREES Special Research Grants Program (TSTAR-C) and the Florida Caladium Growers' Association and approved for publication as Journal Series No. R-10657. We appreciate Dr. R. Hartman's donation of tissue-cultured caladium plants for this study.

${ }^{1}$ To whom reprint requests should be addressed. E-mail: zdeng@mail.ifas.ufl.edu.
$90 \%$ of their roots and $85 \%$ of their leaves within 2-3 weeks after artificial inoculation of Pythium (Deng et al., 2005). Pythium root rot has led to slow and poor production of pot plants in greenhouses, poor plant performance (sparse leaves, stunting, discoloration, etc.), early dieback in landscapes, and significant losses of crops (new tubers) in propagation fields (Gilreath et al., 1999; R.J. McGovern, unpublished data).

Pythium root rot in greenhouse production could be managed with hot water treatment of tubers after harvest and before potting followed by drenching potted plants with fungicides, but control of this disease in propagation fields and landscapes has been very challenging and difficult. Although fungicides could be delivered to the rhizospheres of field-grown plants through fertigation systems, their efficacy is poor in field situation and the cost of installing and operat- ing these systems prevents them from wide adoption and application. Use of disease-resistant cultivars has been an effective and economically viable strategy for integrated management of major diseases in numerous agronomic crops. This strategy could be used to control pythium root rot in caladium if resistant cultivars could be identified or developed. Deng et al. (2005) found that the majority of the 19 major commercial caladium cultivars evaluated were susceptible or very susceptible to Pythium, but four cultivars showed a moderate level of resistance to Pythium. These four cultivars are in two (fancy white and fancy red) of the eight leaf shape/color groups (Bell et al., 1998). The objectives of this study were to 1) screen additional commercial cultivars to identify resistance in other leaf shape/color groups, and 2) evaluate further the relationship between Pythium-incited root rotting and leaf losses.

\section{Materials and methods}

Twenty-three commercial cultivars were used in this study, of which five cultivars ('Blizzard', 'Calypso', 'Cardinal', 'Sunrise', and 'White Ruffles') were released in the last 15 years, while the remaining were bred more than 50 years ago. All these cultivars have been commercially propagated through tuber division (Wilfret, 1993). To avoid possible pathogen contamination of caladium plants from field vegetative propagation, tissue culture plants regenerated from excised shoot tips were obtained from a commercial Florida grower and further increased in greenhouses as described (Deng et al., $2005)$. Plants were grown in six-packs on benches ( $\sim 1 \mathrm{~m}$ aboveground) in a shaded glass greenhouse with $20 \%$ to $30 \%$ light exclusion, a photosynthetic photon flux (PPF) of 600-800 umol $\cdot \mathrm{m}^{-2} \cdot \mathrm{s}^{-1}$, under a natural photoperiod at Bradenton, Fla. The cells of the six-packs were approximately 45 $\mathrm{mL}$ in volume $(3.5 \times 3.5 \times 5.5 \mathrm{~cm}$ at top brim) and were filled with coarse vermiculite amended with Nutricote 13-13-13 (13N-6.4P-10.8K; Scotts

\begin{tabular}{llll}
\hline $\begin{array}{l}\text { Units } \\
\text { To convert U.S. to SI, } \\
\text { multiply by }\end{array}$ & U.S. unit & SI unit & $\begin{array}{l}\text { To convert SI to U.S., } \\
\text { multiply by }\end{array}$ \\
\hline 29.5735 & $\mathrm{fl} \mathrm{oz}$ & $\mathrm{mL}$ & 0.0338 \\
0.3048 & $\mathrm{ft}$ & $\mathrm{m}$ & 3.2808 \\
2.5400 & inch $(\mathrm{es})$ & $\mathrm{cm}$ & 0.3937 \\
$\left({ }^{\circ} \mathrm{F}-32\right) \div 1.8$ & ${ }^{\circ} \mathrm{F}$ & ${ }^{\circ} \mathrm{C}$ & $\left(1.8 \times{ }^{\circ} \mathrm{C}\right)+32$
\end{tabular}


Co., Marysville, Ohio). To maintain sufficient space between plants, only three non-adjacent cells of each sixpack were filled with substrate and used to grow plants. An overhead intermittent mist system was used for plant irrigation; temperatures in the greenhouse were managed to a range of 21 to $32{ }^{\circ} \mathrm{C}$ with a cooling padand-fan system. Plants approximately 8 weeks old, 15 to $30 \mathrm{~cm}$ tall, and with three to six leaves, were inoculated with Pythium.

Pythium inoculum consisting of oospores and hyphae segments was produced as described previously (Deng et al., 2005) from three P. myriotylum isolates $(97-439 \mathrm{~B}, \mathrm{P} 1$, and P2). These isolates originated from rotting roots of either field- or greenhouse-grown plants, and they were virulent and very aggressive in inciting tissue rotting on caladium roots (Deng et al., 2005). Briefly, mycelial mats were produced by growing fugal agar plugs in V8 broth at $31{ }^{\circ} \mathrm{C}$ in the dark overnight, and then induced to produce oospores by washing away nutrients, flooding the mats with sterile, deionized water, and incubating at room temperature for 48 $\mathrm{h}$ under cool-white fluorescent lights. Oospores produced were collected by blending the mats and filtering through four layers of cheesecloth, and diluted with sterile water to desired densities. Oospore suspension solutions from the three isolates were mixed before inoculation.

Pythium inoculation and disease severity evaluation were conducted as described previously (Deng et al., 2005). Plants grown in six-packs were brought into a greenhouse where day and night temperatures were maintained at 30 to $37^{\circ} \mathrm{C}$ and 26 to 28 ${ }^{\circ} \mathrm{C}$, respectively, and placed in plastic saucers $(20 \mathrm{~cm}$ in diameter, $3 \mathrm{~cm}$ deep) that were connected to trickle irrigation tubes and held $1-1.5 \mathrm{~cm}$ water. Plants were allowed to acclimate under this condition for 2-3 weeks. After acclimation, $5 \mathrm{~mL}$ of an oospore suspension from three isolates was applied to the root medium surface of each plant, and $5 \mathrm{~mL}$ of sterile water to each control plant. The density used in Expt. 1 and Expt. 2 was 6000 and 1000 oospores / mL, respectively. The tests were performed in Sept. to early Oct. 2003. Ten days after inoculation, the severity of root tissue rotting and plant leaf losses of each plant were rated on a scale of 1 to 5 , as described previously (Deng et al., 2005), with "l" being $100 \%$ of root tissue rotted, or all leaves wilted or lost, and " 5 " all roots healthy or all leaves normal. Based on root rot ratings, cultivars were categorized into four groups (resistant, moderately resistant, susceptible, or very susceptible). After evaluation, rotting roots were collected from representative plants, disinfected, and cultured on selective media to confirm the presence of $P$. myriotylum in the rotting tissue.

The experiments were performed in a randomized complete-block design with three blocks, and three plants grown in one six-pack placed in one saucer were used as an experimental unit. Analysis of variance, correlation and regression for root rot and leaf loss rating data were performed using the PROC GLM, PROC CORR, and PROC REG procedures in SAS (SAS Institute, 2003); cultivar means for root rot and leaf loss ratings were separated where appropriate.

\section{Results and discussion}

The overall mean root rot score of Expt. 2 was 3.3, slightly higher than that of Expt. 1 (3.0), and the overall mean leaf loss ratings in both experiments were the same (3.1). The root rot scores of three cultivars ('Lance Whorton', 'Pink Gem', and 'Pink Symphony') were quite different between the two experiments (Table 1). Spearman's rank correlation analysis was performed to determine how well the root rotting and leaf loss ratings from the two experiments fit. When all 23 cultivars were included in the analysis, the $r(s)$ values for root rot and leafloss ratings between the two experiments were $0.6338(P=0.0012)$ and $0.4622(P=0.026)$, respectively. With the above three cultivars excluded, the $r(s)$ values for root rot and leaf loss ratings between the two experiments were $0.7938(P<0.0001)$ and 0.58848 $(P=0.0063)$, respectively. These $r(s)$ values were all significant at $P=0.05$ level, indicating an overall consistency of the resistance levels to pythium root rot for the majority of the 23 cultivars between the two experiments. Thus, the root rot ratings and leaf loss ratings from the two experiments for each cultivar were averaged and the mean values were used for cultivar means separation and for categorizing their resistance levels (Table 1 ).

The majority of the 23 cultivars screened were susceptible or highly susceptible to Pythium infection (Table 1). Eight cultivars ('Cardinal', 'Marie Moir', 'Pink Symphony', 'Postman Joyner', 'Rosalie', 'Rosebud', 'Triumph de L'Exposition', and 'White Wing') were highly susceptible to pythium root rot; $35 \%$ to $94 \%$ of their root tissue became rotted within $10 \mathrm{~d}$ after inoculation and they had a rating of 2.9-1.7. 'Rosalie' and 'White Wing', two lance-leaved cultivars, were the most susceptible to pythium root rot; they lost more than $85 \%$ of their roots to rotting within $10 \mathrm{~d}$ after inoculation. Twelve cultivars ('Buck', 'Calypso', 'Jackie Suthers', 'June Bride', 'Kathleen', 'Lance Whorton', 'Mrs. Arno Nehrling, 'Pink Cloud', 'Pink Gem', 'Scarlet Beauty', 'Sunrise', and 'White Ruffles') were susceptible to Pythium infection. They had $15 \%$ to $35 \%$ of their root tissue rotted within $10 \mathrm{~d}$ after inoculation and a rating of 3.9-3.0. Three cultivars ('Etta Moore', 'Apple Blossom', and 'Blizzard') showed a moderate level of resistance to pythium root rot. They scored a root rot rating of $4.0-4.3$, and only $5 \%$ to $14 \%$ of their root tissue was rotted $10 \mathrm{~d}$ after inoculation. The inoculated plants of 'Etta Moore' and 'Blizzard' were maintained for 2 weeks more after the 10th day evaluation, and more than $50 \%$ of their root tissues still appeared healthy by the end of this extra period of time, while the inoculated plants of 'Cardinal' and 'Marie Moir', two very susceptible cultivars, had all their roots rotted due to Pythium infection. $P$. myriotylum was re-isolated from the rotting roots from the inoculated plants. Control plants that received 5 $\mathrm{mL}$ of sterile water in the experiments did not show rotting symptoms during the evaluation.

Pythium infection caused several leaf symptoms on caladium plants, including discoloration and necrotic blotches on blades, epinasty, and wilting on petioles, and whole leaf collapse (Deng et al., 2005). These symptoms were observed again on the 23 cultivars screened and they appeared as early as $3 \mathrm{~d}$ after Pythium inoculation. When the severity of these leaf symptoms was rated on a scale of 1 to 5 , those three cultivars showing moderate root rot resistance maintained an average leaf loss score of 3.9 , the 12 susceptible cultivars had a average score of 3.2 , and the eight very susceptible cultivars had an average score of 2.6 (Table 1 ). 
Table 1. Root rot, leaf loss and resistance levels of commercial caladium cultivars inoculated with P. myriotylum.

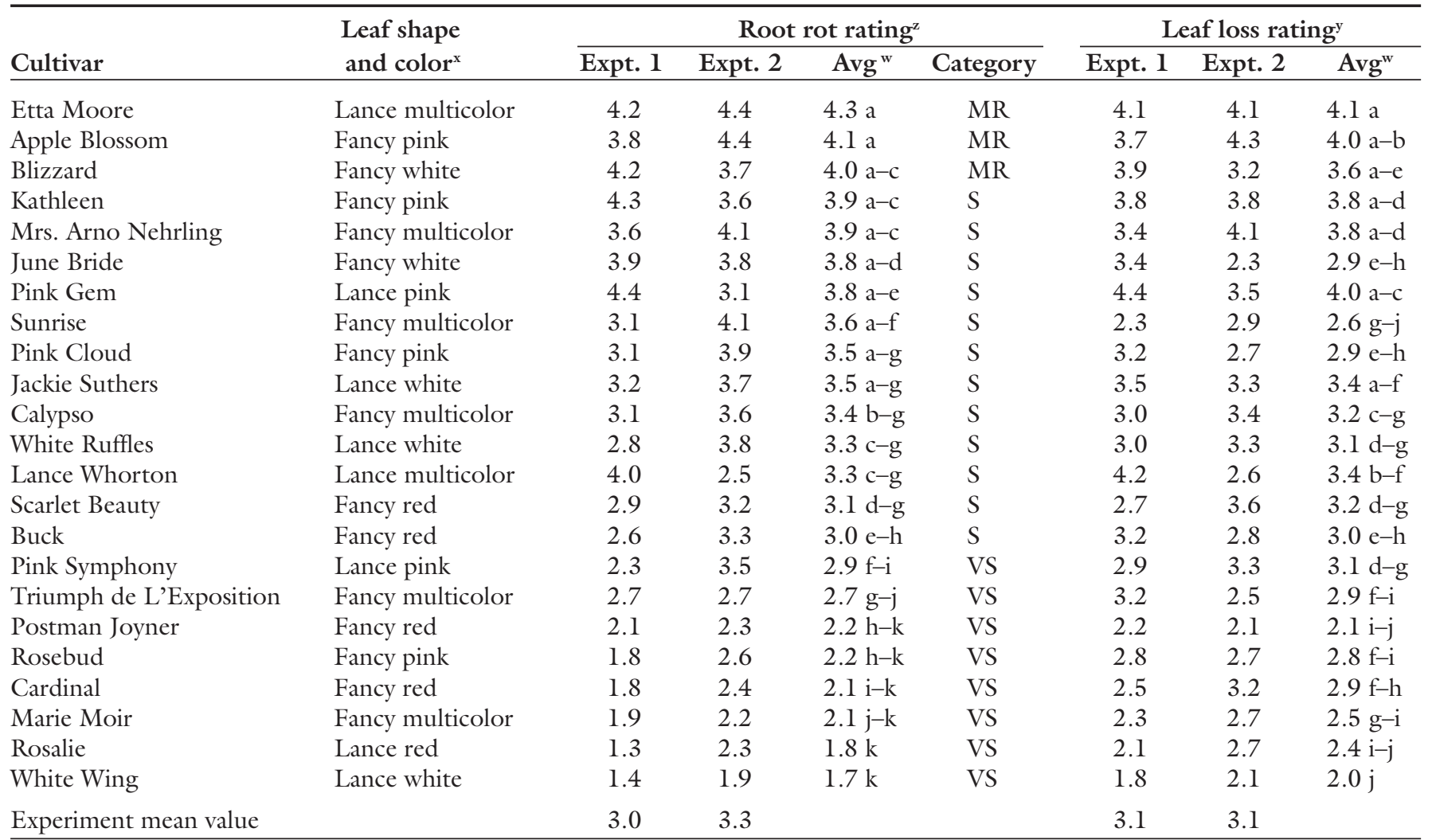

${ }^{2}$ Root rot ratings were made $10 \mathrm{~d}$ after inoculation, on a scale of 1 to 5 , where $1=100 \%, 1.5=95 \%$ to $99 \% ; 2=85 \%$ to $94 \% ; 2.5=84 \%$ to $55 \% ; 3=35 \%$ to $54 \% ; 3.5=15 \%$ to $34 \% ; 4=5 \%$ to $14 \%$; and $4.5=1 \%$ to $4 \%$, respectively, of root tissue on the root ball surface rotted; and $5=$ all roots healthy without any rotting. Resistance to pythium root rot was categorized as follows, $\geq 4.5$ : resistant $(\mathrm{R}),<4.5$ but $\geq 4.0$ : moderately resistant (MR), $<4.0$ but $\geq 3.0$ : susceptible ( ), and $<3.0$ : very susceptible (VS).

Leaf loss ratings were made $10 \mathrm{~d}$ after inoculation, on a scale of 1 to $5: 1=$ all leaves wilted or lost; $2=$ most $(>50 \%)$ leaves wilted or lost; $3=$ some leaves wilted $(\sim 30 \%)$ and showing chlorosis; 4 = almost normal, but showing chlorosis and some stunting; and 5 = all leaves growing normally

'Leaf shape and color classification according to Bell et al. (1998).

"Mean separation within column by SAS GLM procedure and least significant difference (LSD) , $P \leq 0.05$. Numbers in the same column followed by the same letter are not significantly different.

A linear relationship between root rotting scores and leaf loss scores was present in the 19 major caladium cultivars evaluated previously (Deng et al., 2005). This relationship was also observed with the 23 cultivars in this study (Fig. 1) and it was described as $\mathrm{y}=1.1824+0.6178 \mathrm{x}$, where $\mathrm{y}$ is the leaf loss rating and $\mathrm{x}$ is the root tissue rotting score. Regression analysis indicated that it was highly significant, with $P<0.0001$ and an $\mathrm{R}^{2}$ value of 0.58 , which reconfirmed the linear relationship between root rot severity and plant leaf loss. This relationship highlights the importance of effective management of pythium root rot in caladium pot plant and field tuber production, as root tissue rotting caused by Pythium infection could result in rapid and dramatic losses of plant leaves, and consequently lower aesthetic values of pot or landscape plants and tuber yield of propagation fields. In addition, the existence of this relationship might help develop and utilize plant leaf loss scores as an indirect approach for preliminary

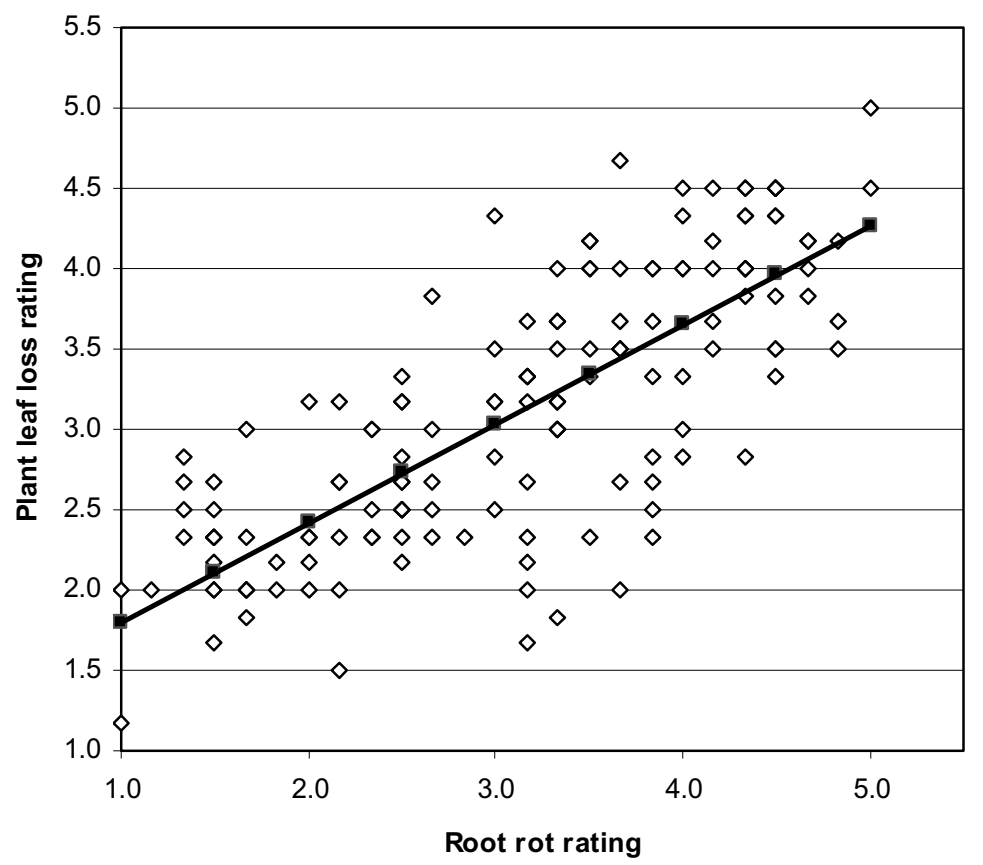

Fig. 1. Linear relationship between root rot scores and leaf loss scores of 23 caladium cultivars inoculated with three Pythium myriotylum isolates. The scores were rated $10 \mathrm{~d}$ after inoculation on a scale of 1 to 5 ; the regression analysis was based on 138 pairs of scores $(\diamond)$, and showed an $F$ value of $189.1(P<0.0001)$. 
Table 2. Distribution of eight leaf/color groups of caladium cultivars in four resistance categories.

\begin{tabular}{|c|c|c|c|c|c|c|}
\hline \multirow{2}{*}{$\begin{array}{l}\text { Leaf } \\
\text { shape }\end{array}$} & \multirow[b]{2}{*}{ Color ${ }^{y}$} & \multirow{2}{*}{$\begin{array}{c}\text { Cultivars } \\
\text { evaluated (no.) }\end{array}$} & \multicolumn{4}{|c|}{ Cultivars in four categories (no. $)^{z}$} \\
\hline & & & $\mathbf{R}$ & MR & $S$ & VS \\
\hline \multirow[t]{4}{*}{ Fancy } & White & 7 & & 4 & 3 & \\
\hline & Red & 7 & & 1 & 2 & 4 \\
\hline & Pink & 8 & & 1 & 5 & 2 \\
\hline & Multicolor & 9 & & & 4 & 5 \\
\hline \multirow[t]{4}{*}{ Lance } & White & 3 & & & 2 & 1 \\
\hline & Red & 3 & & & 1 & 2 \\
\hline & Pink & 3 & & & 3 & \\
\hline & Multicolor & 2 & & 1 & 1 & \\
\hline Total & & 42 & & 7 & 21 & 14 \\
\hline
\end{tabular}

Table 3. Comparison of pythium root rot resistance levels of seven cultivars with their mid-parent values.

\begin{tabular}{llc}
\hline Cultivars & \multicolumn{1}{c}{ Parents $^{\mathrm{z}}$} & $\begin{array}{c}\text { Mid-parent } \\
\text { values }\end{array}$ \\
\hline Blizzard (4.0) & Aaron (3.2) x White Christmas (4.0) & 3.6 \\
Calypso (3.4) & Carolyn Whorton (3.8) x White Christmas (4.0) & 3.9 \\
Cardinal (2.1) & Frieda Hemple (4.4) x Carolyn Whorton (3.8) & 4.1 \\
Fantasy (3.4) & Candidum Jr. (4.0) X Red Frill (2.1) & 3.1 \\
Sunrise (3.7) & Candidum (4.3) x Frieda Hemple (4.4) & 4.4 \\
Sweetheart (3.2) & Candidum Jr. (4.0) x Red Frill (2.1) & 3.1 \\
White Ruffles (3.3) & Aaron (3.2) x Red Frill (2.1) & 2.7 \\
\hline
\end{tabular}

${ }^{2}$ Numbers in parentheses are root rot ratings based on this study and a previous one (Deng et al., 2004).

screening of breeding populations for resistance to this pathogen.

Commercial pot caladium plants are forced from tubers produced in Florida fields (Bell et al., 1998). Commercial tuber production generally starts in March each year and extends over a 7 - to 8 -month period, during which the presence of Pythium in combination with high temperatures and high soil moisture contents could cause significant losses to the caladium growers (Ridings and Hartman, 1976). The three cultivars identified in this screening, plus the four reported previously (Deng et al., 2005), may serve as an integral part of the management strategy to control this soil-borne disease and reduce its damage.

The majority ( 35 out of 42 ) of the cultivars evaluated in this study and in the previous one (Deng et al., 2005) were susceptible or very susceptible to $P$. myriotylum (summarized in Table 2). This highlights the need for development of new resistant cultivars for root rot disease control. Such need is particularly strong in several leaf shape/color groups, as four out of the seven cultivars of moderate resistance are in the fancy white cultivar group, one in the fancy red or pink and lance multicolor group each, and no resistant cultivars identified in the other four groups. The seven cultivars of moderate resistance may serve as an important source of resistance for breeding for new resistant cultivars or for further improvement of caladium resistance to $P$. myriotylum. Previous breeding efforts in caladium primarily targeted improvement of leaf and tuber characters, including new leaf colors or color patterns, tuber yield and branching habits, which might be the reason that the majority of the releases within the last 15 years have low levels of Pythium resistance (lower or much lower than, or only close to their mid-parent values) (Table 3 ). Nevertheless, one of the recent releases, 'Blizzard' (Harbaugh et al., 2002), seems to have moderate resistance to Pythium (Table 1). Comparison of its resistance level to that of its parents ('Aaron' X 'White Christmas') reveals that 'Blizzard' has a resistance level higher than the mid-parent value and is as resistant to Pythium as its resistant parent 'White Christmas' (Table 3). This seems to indicate the potential of developing new cultivars that could be as resistant as these identified cultivars. Artificial screening for pythium root rot resistance was not conducted in the process of developing 'Blizzard' (Harbaugh et al., 2002). The three Pythium isolates used in this study and the previous one (Deng et al., 2005) were very aggressive in inducing root rots in caladium, and they should be very useful in developing rigorous artificial screening procedures. We anticipate that applying artificial disease pressures (induced root rots) should improve the chance of developing new Pythium-resistant caladium varieties.

\section{Literature cited}

Bell, M.L., G.J. Wilfret, and D.A. Devoll. 1998. Survey of caladium tuber producers for acreage of cultivars grown. Proc. Fla. State Hort. Soc. 111:32-34.

Chase, A.R. 1987. Compendium of ornamental foliage plant diseases. APS Press, Amer. Phytopathological Soc., St. Paul, Minn.

Deng, Z., B.K. Harbaugh, R.O. Kelly, T. Seijo and R.J. McGovern. 2005. Pythium root rot resistance in commercial caladium cultivars. HortScience 40:549-552.

Gilreath, J.P., R. McSorley, and R.J. McGovern. 1999. Soil fumigant and herbicide combinations for soilborne pest control in caladium. Pro. Fla. State Hort. Soc. 112:285-290.

Harbaugh, B.K., B.D. Miranda, and G.J. Wilfret. 2002. 'Florida Blizzard'-A white fancy-leaved caladium for large pots or shady landscape. HortScience 37:844-846.

Ridings, W.H and R.D. Hartman. 1976. Pathogenicity of Pythium myriotylum and other species of Pythium to caladium derived from shoot-tip culture. Phytopathology 66:704-709.

SAS Institute. 2003. The SAS system for Windows. Release 8.02. SAS Inst., Cary, N.C.

Wilfret, G.J. 1993. Caladium, p. 239-247. In: A. DeHertogh and M. LeNard (eds.). The physiology of flower bulbs. Elsevier, Amsterdam. 